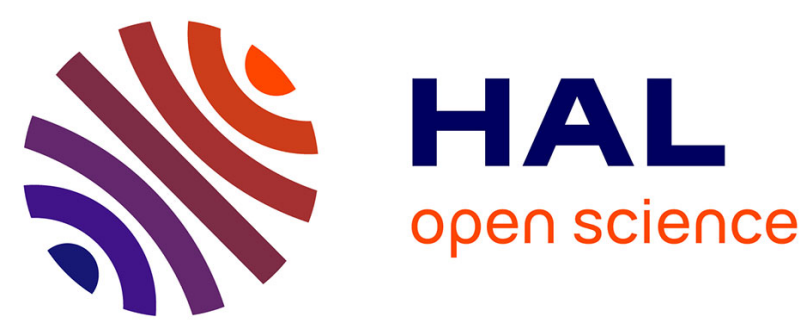

\title{
Nb-Ta fractionation in peraluminous granites: A marker of the magmatic-hydrothermal transition
}

Christophe Ballouard, Marc Poujol, Philippe Boulvais, Yannick Branquet, Romain Tartese, Jean Louis Vigneresse

\section{- To cite this version:}

Christophe Ballouard, Marc Poujol, Philippe Boulvais, Yannick Branquet, Romain Tartese, et al.. $\mathrm{Nb}-\mathrm{Ta}$ fractionation in peraluminous granites: A marker of the magmatic-hydrothermal transition. Geology, 2016, 44 (3), pp.231-234. 10.1130/G37475.1 . insu-01270578

\section{HAL Id: insu-01270578}

\section{https://hal-insu.archives-ouvertes.fr/insu-01270578}

Submitted on 17 Dec 2021

HAL is a multi-disciplinary open access archive for the deposit and dissemination of scientific research documents, whether they are published or not. The documents may come from teaching and research institutions in France or abroad, or from public or private research centers.
L'archive ouverte pluridisciplinaire HAL, est destinée au dépôt et à la diffusion de documents scientifiques de niveau recherche, publiés ou non, émanant des établissements d'enseignement et de recherche français ou étrangers, des laboratoires publics ou privés. 


\section{Geology}

\section{$\mathrm{Nb}$-Ta fractionation in peraluminous granites: a marker of the magmatic-hydrothermal transition \\ --Manuscript Draft--}

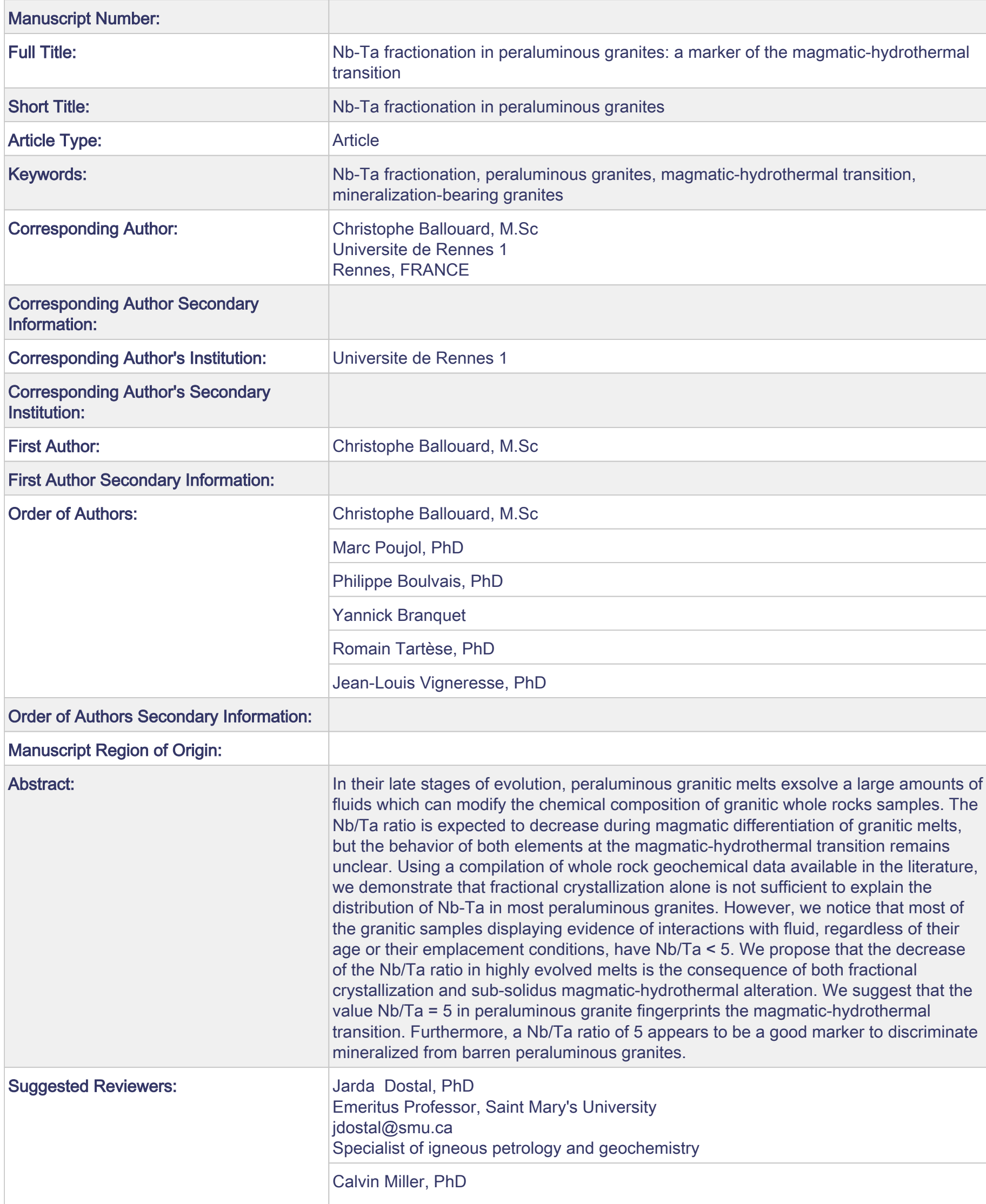


Professor, Vanderbilt University

calvin.f.miller@vanderbilt.edu

Specialist of igneous petrology and magma chamber processes. Reviewer on a first version of this manuscript

Sasha (Aleksandr) Stepanov, PhD

University of Tasmania, Australia

sasha.stepanov@utas.edu.au

Specialist of $\mathrm{Nb}-\mathrm{Ta}$ fractionation during igneous processes

Philippe Muchez, PhD

Professor, KU Leuven, Belgium

philippe.muchez@ees.kuleuven.be

Specialist of igneous processes and metallogeny 


\section{$1 \mathrm{Nb}$-Ta fractionation in peraluminous granites: a marker of the}

2 magmatic-hydrothermal transition

3 Christophe Ballouard ${ }^{1}$, Marc Poujol' ${ }^{1}$, Philippe Boulvais ${ }^{1}$, Yannick Branquet ${ }^{1,2}$, Romain

4 Tartèse $^{3,4}$, Jean-Louis Vigneresse ${ }^{5}$

$5{ }^{1}$ UMR CNRS 6118, Géosciences Rennes, OSUR, Université Rennes 1, 35042 Rennes Cedex,

6 France

$7 \quad{ }^{2}$ Institut des Sciences de la Terre d'Orléans (ISTO), UMR 6113 CNRS/Université

8 d'Orléans/BRGM, Campus Géosciences, 1 A rue de Férolerie, F45071 Orléans Cedex 2, France

9 Institut de Minéralogie,de Physique des Matériaux et de Cosmochimie, Muséum National

10 d'Histoire Naturelle, Sorbonne Universités, CNRS, UMPC \& IRD, 75005 Paris, France

$11{ }^{4}$ Department of Physical Sciences, The Open University, Walton Hall, Milton Keynes, MK7 6AA,

12 United Kingdom

135 Université de Lorraine, UMR 7539 GéoRessources, BP 23, F-54501 Vandoeuvre Cedex, France

15 ABSTRACT

16 In their late stages of evolution, peraluminous granitic melts exsolve a large amounts of fluids

17 which can modify the chemical composition of granitic whole rocks samples. The $\mathrm{Nb} / \mathrm{Ta}$ ratio is

18 expected to decrease during magmatic differentiation of granitic melts, but the behavior of both

19 elements at the magmatic-hydrothermal transition remains unclear. Using a compilation of whole

20 rock geochemical data available in the literature, we demonstrate that fractional crystallization

21 alone is not sufficient to explain the distribution of $\mathrm{Nb}$-Ta in most peraluminous granites.

22 However, we notice that most of the granitic samples displaying evidence of interactions with

23 fluid, regardless of their age or their emplacement conditions, have $\mathrm{Nb} / \mathrm{Ta}<5$. We propose that

24 the decrease of the $\mathrm{Nb} / \mathrm{Ta}$ ratio in highly evolved melts is the consequence of both fractional

25 crystallization and sub-solidus magmatic-hydrothermal alteration. We suggest that the value

$26 \mathrm{Nb} / \mathrm{Ta}=5$ in peraluminous granite fingerprints the magmatic-hydrothermal transition. 
27 Furthermore, a $\mathrm{Nb} / \mathrm{Ta}$ ratio of 5 appears to be a good marker to discriminate mineralized from 28 barren peraluminous granites.

\section{INTRODUCTION}

31 In granitic systems, the magmatic-hydrothermal transition separates a purely magmatic system

32 dominated by crystal-melt interaction from a system dominated by crystal-melt-magmatic fluid

33 phase interaction (Halter and Webster, 2014). Hydrothermal activity in peraluminous granites

34 can be either localized, as evidenced by pegmatites and/or quartz veins, or pervasive, leading to

35 significant element mobility and, in the most extreme cases, to the formation of greisens

36 (Pirajno, 2013). Such alteration events occur during the sub-solidus stage of the granitic melt

37 emplacement and may lead to the deposition of economically significant mineralization such as

38 Sn or W.

$39 \mathrm{Nb}$ and $\mathrm{Ta}$ are lithophile elements considered as "geochemical twins" because they have the

40 same charge and similar ionic radius. As a result they have similar geochemical properties and

41 should not be fractionated during most geological processes (Goldschmidt, 1937). However, in

42 granitic rocks, $\mathrm{Nb} / \mathrm{Ta}$ ratios are highly variable ( $<2-25$; Green, 1995). Some authors have

43 demonstrated that the $\mathrm{Nb} / \mathrm{Ta}$ ratios decrease in granites during fractional crystallization

44 (Raimbault et al. 1995; Linnen and Keppler, 1997; Stepanov et al., 2014). Other studies have

45 suggested that $\mathrm{Nb}$ and $\mathrm{Ta}$ could be fractionated in highly evolved peraluminous granites during

46 the interaction with late magmatic fluids (Dostal and Chatterjee, 2000; Tartèse and Boulvais,

47 2010; Ballouard et al., 2015; Dostal et al., 2015). 
49 In order to decipher the specific role of the magmatic and hydrothermal processes on the

50 evolution of the $\mathrm{Nb} / \mathrm{Ta}$ ratios, we compiled whole rock geochemical data available in the

51 literature for peraluminous granites emplaced at different times and in various tectonic contexts.

52 Based on these data, we show that fractional crystallization of granitic melts alone is not

53 sufficient to account for the $\mathrm{Nb}$-Ta behavior observed in most peraluminous granites and that

54 hydrothermal processes are necessarily involved.

56 PRESENT KNOWLEDGE

\section{Magmatic behavior of $\mathrm{Nb}-\mathrm{Ta}$}

58 In highly evolved granites and pegmatites, columbite $\left((\mathrm{Fe}, \mathrm{Mn}) \mathrm{Nb}_{2} \mathrm{O}_{6}\right)$ and tantalite $((\mathrm{Fe}$,

$59 \mathrm{Mn}) \mathrm{Ta}_{2} \mathrm{O}_{6}$ ) are the main mineral phases hosting $\mathrm{Nb}$ and $\mathrm{Ta}$. Experimental studies have shown

60 that the solubility of these two minerals in granitic melts increases with temperature, but

61 decreases with increasing the Aluminium Saturation Index (ASI), a parameter related to the

62 degree of polymerization of the melt (Linnen and Keppler, 1997; Aseri et al., 2015). The Li

63 content of granitic melts also increases the solubility of columbite and tantalite (Linnen, 1998;

64 Aseri et al., 2015).

65 Partial melting can produce granitic peraluminous melts with $\mathrm{Nb} / \mathrm{Ta}$ ratios higher or lower than

66 their source, depending on the temperature. Melts formed during high temperature anatexis tend

67 to have high $\mathrm{Nb} / \mathrm{Ta}$ ratios, as a result of the complete consumption of biotite and the high

68 abundance of Ti-bearing oxides in the residue, which preferentially incorporate $\mathrm{Ta}$ over $\mathrm{Nb}$

69 (Stepanov et al., 2014). Conversely, low temperature partial melting generates melts with low

$70 \mathrm{Nb} / \mathrm{Ta}$ ratios because residual biotite incorporates preferentially $\mathrm{Nb}$ over $\mathrm{Ta}$ (Stepanov et al.,

71 2014). Since biotite and Ti-bearing minerals can also be involved during differentiation of 
72 granitic melts, fractional crystallization also changes $\mathrm{Nb} / \mathrm{Ta}$ ratios: $\mathrm{Nb} / \mathrm{Ta}$ increases during high

73 temperature fractional crystallization of Ti-rich melts due to the preferential saturation of Ti-

74 oxide minerals over biotite, whereas $\mathrm{Nb} / \mathrm{Ta}$ ratios decrease during low temperature

75 differentiation of granitic melts due to the fractionation of biotite and/or muscovite (Stepanov et

76 al., 2014). In the most evolved peraluminous melts, the lower solubility of manganocolumbite

$77\left(\mathrm{MnNb}_{2} \mathrm{O}_{6}\right)$ compared to manganotantalite $\left(\mathrm{MnTa}_{2} \mathrm{O}_{6}\right)$ also enhances the decrease of the $\mathrm{Nb} / \mathrm{Ta}$

78 ratio in the melt (Linnen and Keppler, 1997).

79 Melt inclusions in Li-F granites (Orlovka massif, Eastern Transbaikalia) indicate a separation of

80 an immiscible F-rich hydrosaline melt that can induce a decrease of the $\mathrm{Nb}$ and Ta contents in

81 the residual melt (Badanina et al., 2010).

82

\section{Nb-Ta behavior in hydrothermal systems}

$84 \mathrm{Nb}$ and $\mathrm{Ta}$ are poorly soluble in aqueous solutions, Ta being even less soluble than $\mathrm{Nb}$ (Zaraisky

85 et al., 2010). Experiments with aqueous F-rich fluids and aluminosilicate melt indicate that $\mathrm{Nb}$

86 and Ta preferentially partition in the melt (Chevychelov et al., 2005). However, the solubility

87 and hydrothermal transfer of $\mathrm{Ta}$ and $\mathrm{Nb}$ are greatly enhanced in F-rich solutions under reducing

88 conditions (Zaraisky et al., 2010). These experimental results are consistent with the fact that

89 several F-rich cupolas of greisenized peraluminous granites are significantly enriched in both $\mathrm{Nb}$

90 and Ta (e.g.Zaraisky et al., 2009).

91

92 VARIATIONS OF WHOLE ROCK NB/TA RATIOS IN PERALUMINOUS GRANITES 
93 We compiled data for peraluminous granites (i.e., with a A/CNK ratio > 1) as well as for some

94 greisens of different ages (Archean to Mesozoic) and emplaced in various geodynamical contexts

95 (see Table DR1 in the GSA Data Repository).

\section{Nb-Ta fractionation during magmatic processes}

98 In Figure 1, the $\mathrm{Nb} / \mathrm{Ta}$ ratios are highly variable between $\sim 15$ and $\sim 0$ when reported as a function 99 of $\mathrm{Nb}$ and $\mathrm{Ta}$, the lowest values being recorded by whole rocks displaying the highest $\mathrm{Nb}$ and $\mathrm{Ta}$ 100 contents. Mica fractionation in granitic melt induces a decrease of the $\mathrm{Nb} / \mathrm{Ta}$ ratios (Stepanov et 101 al., 2014). In Figure 1, we modeled the evolution of a melt with an initial $\mathrm{Ta}$ and $\mathrm{Nb}$ contents of $1021.5 \mathrm{ppm}$ and $12 \mathrm{ppm}(\mathrm{Nb} / \mathrm{Ta}=8)$, respectively, undergoing fractionation of a cumulate made of

$10380 \mathrm{wt} . \%$ (quartz + feldspar) + $10 \mathrm{wt} . \%$ muscovite + 10wt.\% biotite, using the Rayleigh

104 distillation law and the silicate-melt partition coefficients compiled by Stepanov et al. (2014).

105 The modeling qualitatively reproduces the behaviors of $\mathrm{Nb}$ and $\mathrm{Ta}$, but it requires an unrealistic 106 rate of mineral fractionation (over $90 \mathrm{wt} . \%$ ) to reach low $\mathrm{Nb} / \mathrm{Ta}$ ratios around 2 and $\mathrm{Nb}$ and $\mathrm{Ta}$ 107 contents around 20 and 10 ppm, respectively (Fig. 1). The addition of 0.5 wt.\% Fe-Ti oxide

108 (e.g.ilmenite or rutile) in the cumulate, in which $\mathrm{Ta}$ and $\mathrm{Nb}$ are highly compatibles (Stepanov et 109 al., 2014), makes things even worse. Indeed, the fractionation of this cumulate causes a decrease 110 of the $\mathrm{Nb}$ content (Fig. 1A), resulting in a trend opposite to the trend displayed by the 111 peraluminous granites.

112 If crystal-melt fractionation is likely to occur during the crystallization of granitic melts in 113 magmatic bodies (Dufek and Bachmann, 2010) and during the magma ascent in dykes (Tartèse 114 and Boulvais, 2010; Yamato et al., 2012), numerical modeling shows that the efficiency of 115 crystal-melt segregation is restricted to cases where crystals represent a low percentage of the 
116 total magma volume (Yamato et al., in press). Indeed, 70-75\% of crystallization marks the

117 particle locking threshold (PLT in Figure 1B, Vigneresse et al., 1996) where the liquid becomes

118 totally locked, precluding any crystal-melt segregation. The model presented here thus suggests

119 that fractional crystallization alone is not sufficient to explain the behaviors of $\mathrm{Nb}$ and $\mathrm{Ta}$ in 120 peraluminous granitic rocks.

\section{$122 \mathrm{Nb}$-Ta fractionation during magmatic-hydrothermal processes}

\section{Mineralogical markers}

124 Secondary muscovitization and greisenization occur under sub-solidus conditions during the 125 interaction between crystallized granites and acidic late magmatic fluids (Pirajno, 2013). The

126 Figure 2 shows that the $\mathrm{Nb} / \mathrm{Ta}$ ratios of whole rock granites and greisens are anti-correlated with 127 the average $\mathrm{MgO} /\left(\mathrm{Na}_{2} \mathrm{O}+\mathrm{TiO}_{2}\right)$ ratios of the muscovite they host (a chemical marker for 128 secondary muscovitization, Miller et al., 1981). This observed anti-correlation suggests that the 129 fluids involved in the secondary muscovitization processes could also be responsible for the 130 decrease of the $\mathrm{Nb} / \mathrm{Ta}$ whole-rock values. Whole rock hydrothermal enrichment of Ta during 131 secondary muscovitization is, for example, observed in ongonites (topaz-bearing 132 microleucogranites) from the Ongon Kairkhan (Mongolia) and this process is associated with the 133 crystallization of late Ta-rich overgrowth on Nb-Ta oxides (Dostal et al., 2015).

\section{Geochemical markers}

136 The whole rock $\mathrm{Nb} / \mathrm{Ta}$ ratios of peraluminous granites are anti-correlated with their $\mathrm{Sn}$ contents, 137 an element highly mobilized at the magmatic-hydrothermal transition (Fig. 3A): high Sn contents 138 above $\sim 30 \mathrm{ppm}$ are only encountered in granitic samples (or greisens) with low $\mathrm{Nb} / \mathrm{Ta}(<5)$. 
139 These samples also display high contents in Cs, F, Li, W and Rb. Because such incompatible 140 elements present a strong affinity for magmatic fluids, their enrichment is commonly used as a

141 marker of a magmatic-hydrothermal alteration in highly evolved crustal granites. Indeed,

142 increasing the abundance of highly incompatible elements, with a bulk partition coefficient Kd

143 between the mineral phases and the melt close to 0 , by two orders of magnitude, as observed in

144 Figure 3A (from $\sim 10$ to $\sim 1000 \mathrm{ppm}$ ), during fractional crystallization requires a unrealistic

145 degree of fractional crystallization up to $99 \mathrm{wt} \%$, suggesting that hydrothermal processes are

146 also involved. Such enrichments in highly incompatible element, attributed to interaction with

147 magmatic fluids, have been noticed in the Erzgebirge massif (Förster et al., 1999), in the South

148 Mountain Batholith (e.g. Dostal and Chatterjee, 2000), or in the French Armorican Massif

149 (Tartèse and Boulvais, 2010; Ballouard et al., 2015).

$151 \mathrm{The} \mathrm{Nb} / \mathrm{Ta}$ ratios also correlate with the $\mathrm{K} / \mathrm{Rb}$ ratios (Fig. 3B). Most granites with low $\mathrm{Nb} / \mathrm{Ta}$

152 display $\mathrm{K} / \mathrm{Rb}$ values lower than 150 , characteristic of the pegmatite-hydrothermal evolution

153 (Shaw, 1968). Such a tendency is observed in the South Mountain Batholith, where it was

154 interpreted as evidence for a magmatic-hydrothermal alteration (Dostal and Chatterjee, 2000).

156 Finally, the whole rock $\mathrm{Nb} / \mathrm{Ta}$ ratios can be compared with the magnitude of the tetrad effect,

157 which corresponds to the intra-REE fractionation observed in the REE patterns of highly

158 fractionated magmatic rocks and hydrothermal precipitates (e.g. Irber, 1999). Although Duc-Tin

159 and Kepller (2015) have recently suggested that the tetrad effect could result from monazite and

160 xenotime fractionation, most authors have argued that such REE patterns actually reflect a

161 selective complexation of the REE during the interaction of granitic melts with F- and Cl-rich 
162 aqueous fluids (e.g. Bau, 1996; Irber, 1999; Monecke et al., 2007). Irber (1999) quantified the

163 degree of tetrad effect $\left(\mathrm{TE}_{1-3}\right)$ by determining the deviation of the first and the third tetrad of

164 granites REE-patterns from a hypothetical tetrad effect-free REE pattern. The large majority of

165 the samples with significant tetrad effect $\left(\mathrm{TE}_{1-3}>1.1\right)$ are also characterized by low $\mathrm{Nb} / \mathrm{Ta}$ ratios

166 below $\sim 5$ (Fig.3C).

167

168 Metallogenic markers

$169 \mathrm{The} \mathrm{Nb} / \mathrm{Ta}$ ratio is commonly compared to the $\mathrm{Zr} / \mathrm{Hf}$ ratio, as the latter has been proposed as

170 either a marker of magmatic-hydrothermal interactions (Bau, 1996) or of fractional

171 crystallization (Linnen and Keppler, 2002; Claiborne et al., 2006). The $\mathrm{Zr} / \mathrm{Hf}$ ratio is a

172 geochemical indicator of the fertility of granitic rocks as a $\mathrm{Zr} / \mathrm{Hf}$ ratios below $\sim 25$

173 (corresponding to the lower limit of the CHArge and RAdius Control range; Bau, 1996) are

174 expected in granites where Sn, W, Mo, Be and Ta mineralization are described (Zaraisky et al.,

175 2009). In a Nb/Ta vs. Zr/Hf diagram (Fig. 4), most barren granites plot in the field defined by 26

$176<\mathrm{Zr} / \mathrm{Hf}<46(\mathrm{CHARAC}$ range of Bau, 1996) and by $5<\mathrm{Nb} / \mathrm{Ta}<16$, whereas peraluminous

177 granites associated with $\mathrm{Sn}, \mathrm{W}$ and/or $\mathrm{U}$ deposits have $18<\mathrm{Zr} / \mathrm{Hf}<46$ with $\mathrm{Nb} / \mathrm{Ta}$ ratio lower

178 than 5 . Rare metals granites are characterized by even lower $\mathrm{Zr} / \mathrm{Hf}$ ratios $(<18)$ with $\mathrm{Nb} / \mathrm{Ta}$

179 ratios that are still lower than 5.

180

181 From the diagrams presented in Figures 2, 3 and 4, we highlight significant mineralogical

182 (secondary muscovitization), geochemical ( $\mathrm{Sn}$ contents, $\mathrm{K} / \mathrm{Rb}$ ratio, tetrad effect) and

183 metallogenic (Sn-W-U and rare metal mineralization) evidence that magmatic-hydrothermal

184 processes account for the decrease of the $\mathrm{Nb} / \mathrm{Ta}$ ratio in peraluminous granites. The solubility 
185 and hydrothermal transfer of $\mathrm{Nb}$ and $\mathrm{Ta}$ are greatly enhanced, by up to three orders of

186 magnitude, in reduced F-rich aqueous solutions (Zaraisky et al., 2010). Therefore, in

187 peraluminous granites affected by sub-solidus alteration, the $\mathrm{Nb} / \mathrm{Ta}$ ratios can be lowered by an

188 increase of the Ta content in Ta-Nb-bearing minerals due to the lower mobility of Ta compared

189 to $\mathrm{Nb}$ in aqueous solutions. As a consequence, we suggest here that the decrease of the $\mathrm{Nb} / \mathrm{Ta}$

190 ratios to values lower than $\sim 5$ in peraluminous granites reflects the concomitant effect of

191 fractional crystallization and sub-solidus magmatic-hydrothermal alteration, likely by F-rich

192 acidic reduced fluids of magmatic origin.

193

$194 \mathrm{Nb} / \mathrm{Ta}=5$ : a critical ratio for granite petrogenesis and mineral exploration strategies

195 The peraluminous granite whole rock samples with $\mathrm{Nb} / \mathrm{Ta}$ ratios lower than 5 show significant 196 evidence of interaction with fluids. We suggest that $\mathrm{Nb} / \mathrm{Ta}=5$ represents a threshold between a 197 purely magmatic system $(\mathrm{Nb} / \mathrm{Ta}>5)$ and a magmatic-hydrothermal system $(\mathrm{Nb} / \mathrm{Ta}<5)$. Taking 198 a cut off value of 5 for the $\mathrm{Nb} / \mathrm{Ta}$ ratio as a marker of the magmatic-hydrothermal transition in 199 peraluminous granites bears some implications for exploration strategies as it can also help to 200 define the economic potential of these granites. Indeed, Figure 4 demonstrates that a $\mathrm{Nb} / \mathrm{Ta}$ ratio 201 of 5 can be used as a geochemical indicator to differentiate barren granites from granites 202 spatially related to $\mathrm{Sn}-\mathrm{W}-(\mathrm{U})$ or rare metals mineralization. Since whole rock trace element 203 analyses (including $\mathrm{Nb}$ and $\mathrm{Ta}$ ) are routinely performed in most laboratories around the world, 204 the simple calculation of whole rock sample $\mathrm{Nb} / \mathrm{Ta}$ ratios can, therefore, help exploration 205 geologists to define potential targets for Sn-W-(U) and rare metals deposits.

\section{CONCLUSION}


The mineralogical and geochemical evidence of fluid interaction recorded in granitic whole rock

209 samples, indicate that the value $\mathrm{Nb} / \mathrm{Ta}=5$ is a good marker of the magmatic-hydrothermal

210 transition in peraluminous granites. The decrease of the $\mathrm{Nb} / \mathrm{Ta}$ ratio in peraluminous granites is

211 associated with an increase of the degree of secondary muscovitization and with geochemical

212 and metallogenic evidence of hydrothermal interactions, suggesting that sub-solidus alteration is

213 involved in the fractionation of $\mathrm{Nb}-\mathrm{Ta}$. To further constrain the mechanisms involved in the

214 fractionation of $\mathrm{Nb} / \mathrm{Ta}$ ratios in peraluminous granites at the magmatic-hydrothermal transition,

215 mineral-scale analyses would now be required. From an exploration point of view, and based on

216 the large compilation of data presented in this study, the $\mathrm{Nb} / \mathrm{Ta}$ ratio appears to be a good

217 geochemical indicator to differentiate barren from ore-bearing peraluminous granites.

\section{ACKNOWLEDGMENTS}

220 We acknowledge Calvin Miller and two anonymous referees for their fruitful comments on a

221 previous version of this manuscript.

\section{REFERENCES CITED}

224 Aseri, A.A., Linnen, R.L., Che, X.D., Thibault, Y., Holtz, F., 2015, Effects of fluorine on the 225 solubilities of $\mathrm{Nb}, \mathrm{Ta}, \mathrm{Zr}$ and $\mathrm{Hf}$ minerals in highly fluxed water-saturated haplogranitic 226 melts: Ore Geology Reviews,v. 64, 736-746, doi:10.1016/j.oregeorev.2014.02.014.

227 Ballouard C., Boulvais P., Poujol M., Gapais D., Yamato P., Tartèse R., Cuney M., 2015, 228 Tectonic record, magmatic history and hydrothermal alteration in the HercynianGuérandeleucogranite, Armorican Massif, France:Lithos,v. 220-223, 1-22, doi:10.1016/j.lithos.2015.01.027.

Badanina, E.V., Syritso, L.F., Volkova, E.V., Thomas, R., Trumbull, R.B., 2010. Composition of Li-F granite melt and its evolution during the formation of the ore-bearing Orlovka massif in Eastern Transbaikalia: Petrology, v. 18, 131-157. doi:10.1134/S0869591110020037 
Bau M., 1996, Controls on the fractionation of isovalent trace elements in magmatic and aqueous systems: evidence from $\mathrm{Y} / \mathrm{Ho}, \mathrm{Zr} / \mathrm{Hf}$, and lanthanide tetrad effect: Contribution to Mineralogy and Petrology,v. 123, 323-333, doi: 10.1007/s004100050159.

Chevychelov V.Y., Zaraisky G.P., Borisovskii S.E., Borkov D.A., 2005, Effect of melt composition and temperature on the partitioning of $\mathrm{Ta}, \mathrm{Nb}, \mathrm{Mn}$, and $\mathrm{F}$ between granitic (alkaline) melt and fluorine-bearing aqueous fluid: Fractionation of $\mathrm{Ta}$ and $\mathrm{Nb}$ and conditions of ore formation in rare-metal granites [Translated from Petrologiya, v. 13, no. 4, 2005, pp. 339-357]: Petrology, v. 13:305-321.

Claiborne, L.L., Miller, C.F., Walker, B.A., Wooden, J.L., Mazdab, F.K., Bea, F., 2006. Tracking magmatic processes through $\mathrm{Zr} / \mathrm{Hf}$ ratios in rocks and $\mathrm{Hf}$ and $\mathrm{Ti}$ zoning in zircons: An example from the Spirit Mountain batholith, Nevada: Mineralogical Magazine, v. 70, 517-543, doi: 10.1180/0026461067050348.

Dostal, J., Chatterjee, A.K., 2000, Contrasting behaviour of $\mathrm{Nb} / \mathrm{Ta}$ and $\mathrm{Zr} / \mathrm{Hf}$ ratios in a peraluminous granitic pluton (Nova Scotia, Canada): Chemical Geology, v. 163, 207-218, doi:10.1016/S0009-2541(99)00113-8.

Dostal, J., Kontak, D.J., Gerel, O., Gregory Shellnutt, J., Fayek, M., 2015. Cretaceous ongonites (topaz-bearing albite-rich microleucogranites) from Ongon Khairkhan, Central Mongolia: Products of extreme magmatic fractionation and pervasive metasomatic fluid: rock interaction: Lithos, v. 236-237, 173-189. doi:10.1016/j.lithos.2015.08.003.

Duc-Tin, Q., Keppler, H., 2015. Monazite and xenotime solubility in granitic melts and the origin of the lanthanide tetrad effect: Contributions to Mineralogy and Petrology,v. 169, doi:10.1007/s00410-014-1100-9.

Dufek, J., Bachmann, O., 2010. Quantum magmatism: Magmatic compositional gaps generated by melt-crystal dynamics: Geology,v. 38, 687-690. doi:10.1130/G30831.1

Goldschmidt, V.M., 1937, The principles of distribution of chemical elements in minerals and rocks. The seventh Hugo Müller Lecture delivered before the Chemical Society on March 17th, 1937: Journal of the Chemical Society Resumed 655-673, doi: 10.1039/JR9370000655.

Green, T.H., 1995, Significance of $\mathrm{Nb} / \mathrm{Ta}$ as an indicator of geochemical processes in the crustmantle system: Chemical Geology, v. 120, 347-359, doi: 10.1016/0009-2541(94)00145-X. 
Halter, W.E., Webster, J.D., 2004, The magmatic to hydrothermal transition and its bearing on ore-forming systems: Chemical Geology, v. 210, 1-6, doi:10.1016/j.chemgeo.2004.06.001.

Pirajno, F., 2013, Effects of Metasomatism on Mineral Systems and Their Host Rocks: Alkali

\section{Metasomatism, Skarns, Greisens, Tourmalinites, Rodingites, Black-Wall Alteration and} Listevenites, in:Harlov, D.E., Austrheim, H.,Metasomatism and the Chemical Transformation of Rock, Lecture Notes in Earth System Sciences, Springer Berlin Heidelberg, pp. 203-252.

Irber, W., 1999, The lanthanide tetrad effect and its correlation with $\mathrm{K} / \mathrm{Rb}, \mathrm{Eu} / \mathrm{Eu}{ }^{*}, \mathrm{Sr} / \mathrm{Eu}, \mathrm{Y} / \mathrm{Ho}$, and $\mathrm{Zr} / \mathrm{Hf}$ of evolving peraluminous granite suites: Geochimica et Cosmochimica Acta, v. 63, 489-508,doi: 10.1016/S0016-7037(99)00027-7.

Linnen, R.L., 1998, The solubility of Nb-Ta-Zr-Hf-W in granitic melts with $\mathrm{Li}$ and $\mathrm{Li}+\mathrm{F}$; constraints for mineralization in rare metal granites and pegmatites: Economic Geology, v. 93, 1013-1025, doi:10.2113/gsecongeo.93.7.1013.

Linnen, R.L., Keppler, H., 1997, Columbite solubility in granitic melts: consequences for the enrichment and fractionation of $\mathrm{Nb}$ and $\mathrm{Ta}$ in the Earth's crust: Contribution to Mineralogy and Petrology, v. 128, 213-227, doi:10.1007/s004100050304.

Linnen, R.L., Keppler, H., 2002, Melt composition control of Zr/Hf fractionation in magmatic processes: Geochimica et Cosmochimica Acta, v. 66, 3293-3301, doi: 10.1016/S00167037(02)00924-9.

Miller, C.F., Stoddard, E.F., Bradfish, L.J., Dollase, W.A., 1981, Composition of plutonic muscovite; genetic implications: The Canadian Mineralogist, v. 19, 25-34.

Monecke, T., Dulski, P., Kempe, U., 2007. Origin of convex tetrads in rare earth element patterns of hydrothermally altered siliceous igneous rocks from the Zinnwald Sn-W deposit, Germany: Geochimica et Cosmochimica Acta, v.71, 335-353. doi:10.1016/j.gca.2006.09.010

Raimbault, L., Cuney, M., Azencott, C., Duthou, J.-L., Joron, J.L., 1995. Geochemical evidence for a multistage magmatic genesis of Ta-Sn-Li mineralization in the granite at Beauvoir, French Massif Central: Economic Geology, v. 90, 548-576. doi:10.2113/gsecongeo.90.3.548

Rudnick R., Gao S., 2005, Composition of the Continental Crust. In: Treatise on Geochemistry. Holland H.D., Turekian K.K., ed., Elsevier, Amsterdam, v. 3, 1-64. 
Shaw D., 1968, A review of K-Rb fractionation trends by covariance analysis: Geochimica et Cosmochimica Acta, v. 32, 573-601, doi: 10.1016/0016-7037(68)90050-1.

Stepanov, A., Mavrogenes, J.A., Meffre, S., Davidson, P., 2014, The key role of mica during igneous concentration of tantalum: Contribution to Mineralogy and Petrology, v. 167, 1-8, doi: 10.1007/s00410-014-1009-3.

Tartèse, R., Boulvais, P., 2010, Differentiation of peraluminous leucogranites "en route" to the surface: Lithos, v. 114, 353-368, doi:10.1016/j.lithos.2009.09.011.

Vigneresse, J.L., Barbey, P., Cuney, M., 1996. Rheological Transitions During Partial Melting and Crystallization with Application to Felsic Magma Segregation and Transfer. Journal of Petrology, v. 37, 1579-1600. doi:10.1093/petrology/37.6.1579

Yamato, P., Tartèse, R., Duretz, T., May, D.A., 2012. Numerical modelling of magma transport in dykes: Tectonophysics, v. 526-529, 97-109. doi:10.1016/j.tecto.2011.05.015

Yamato, P., Duretz, T., May, D.A., Tartèse, R., in press. Quantifying magma segregation in dykes: Tectonophysics. doi:10.1016/j.tecto.2015.08.030

Zaraisky, G.P., Aksyuk, A.M., Devyatova, V.N., Udoratina, O.V., Chevychelov, V.Y., 2009, The $\mathrm{Zr} / \mathrm{Hf}$ ratio as a fractionation indicator of rare-metal granites: Petrology, v. 17, 25-45, doi:10.1134/S0869591109010020 
Figure 1.Nb/Ta vs. (A) $\mathrm{Nb}$ and (B) Ta abundances for peraluminous granites. The colored curves 330 represent a model of evolution of $\mathrm{Nb}$ and $\mathrm{Ta}$ in a liquid $\mathrm{L}_{0}(\mathrm{Nb}=12 \mathrm{ppm}, \mathrm{Ta}=1.5 \mathrm{ppm}, \mathrm{Nb} / \mathrm{Ta}=$

331 8) during the fractionation of an assemblage made of $10 \mathrm{wt} . \%$ biotite $+10 \mathrm{wt} . \%$ muscovite +80

332 wt.\% (quartz + feldspar). The numbers above the curves indicate the amount of fractional

333 crystallization. The black dashed line represents the same model during the fractionation of an 334 assemblage composed of $10 \mathrm{wt} . \%$ biotite $+10 \mathrm{wt} . \%$ muscovite $+0.5 \mathrm{wt} . \%$ ilmenite $+79.5 \mathrm{wt} . \%$

335 (quartz + feldspar). The Kd used and presented in the table in inset in the diagram are from

336 Stepanov et al. (2014) and reference therein. PLT: Particle Locking Threshold (Vigneresse et al., 337 1996).

Figure 2. (A) Mg-Na-Ti ternary classification diagram of muscovite (Miller et al., 1981). (B)

341 Diagram reporting the evolution of $\mathrm{Nb} / \mathrm{Ta}$ ratios for whole rock samples from different

342 peraluminous granites against the average value of the $\mathrm{MgO} /\left(\mathrm{Na}_{2} \mathrm{O}+\mathrm{TiO}_{2}\right)$ ratios of their 343 diochtaedral micas.

Figure 3: Evolution of $\mathrm{Nb} / \mathrm{Ta}$ ratios of peraluminous granites as a function of selected markers of magmatic-hydrothermal alteration. The degree of tetrad effect $\left(\mathrm{TE}_{1-3}\right)$ has beencalculated using the equation of Irber (1999). CC: Continental Crust composition (from Rudnick and Gao, 2005). 
$357{ }^{1}$ GSA Data Repository item 2015xxx, [Synthesis of peraluminous crustal granites reported in 358 this study], is available online at www.geosociety.org/pubs/ft2015.htm, or on request from 359 editing@geosociety.org or Documents Secretary, GSA, P.O. Box 9140, Boulder, CO 80301, 360 USA. 

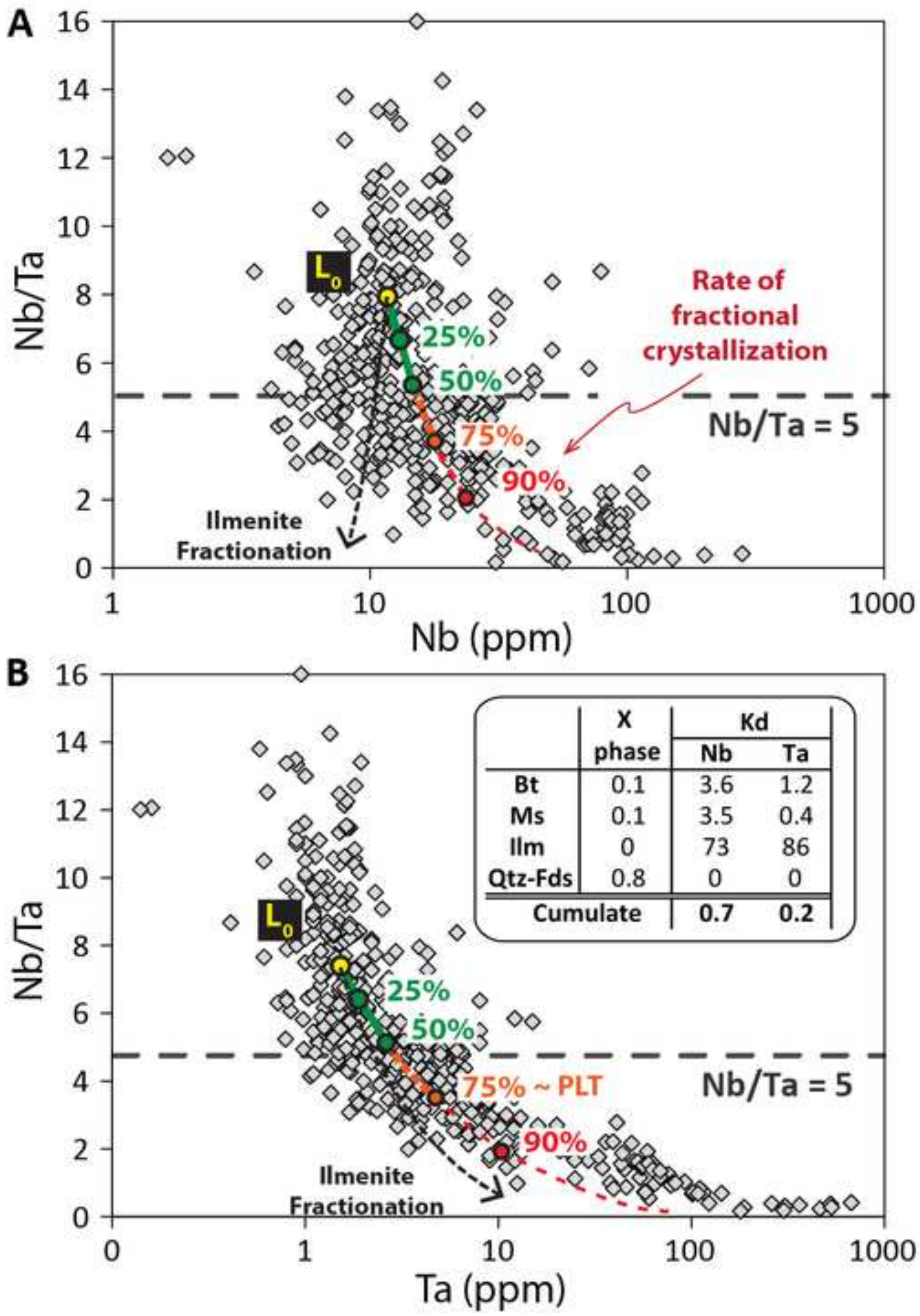


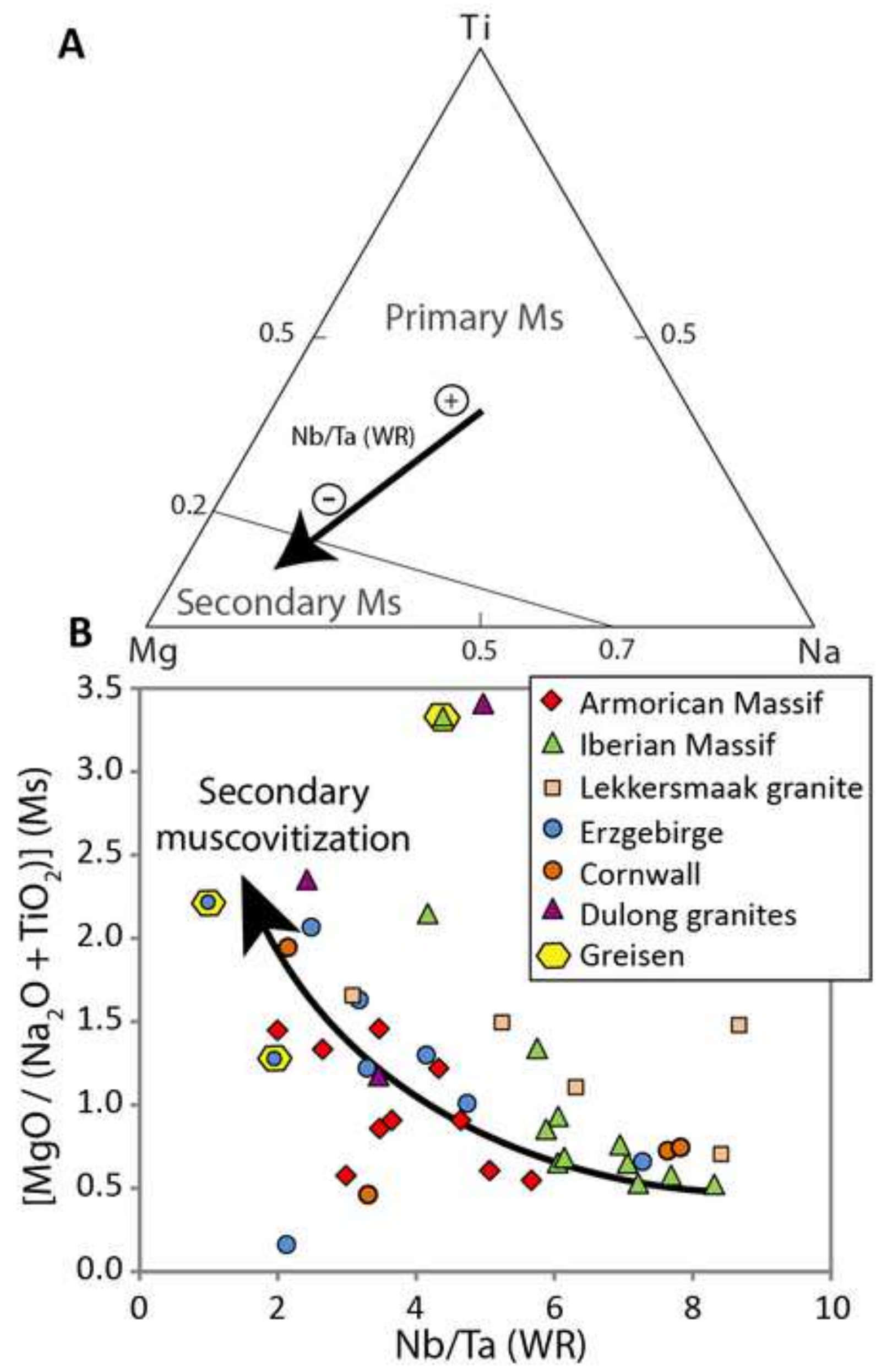



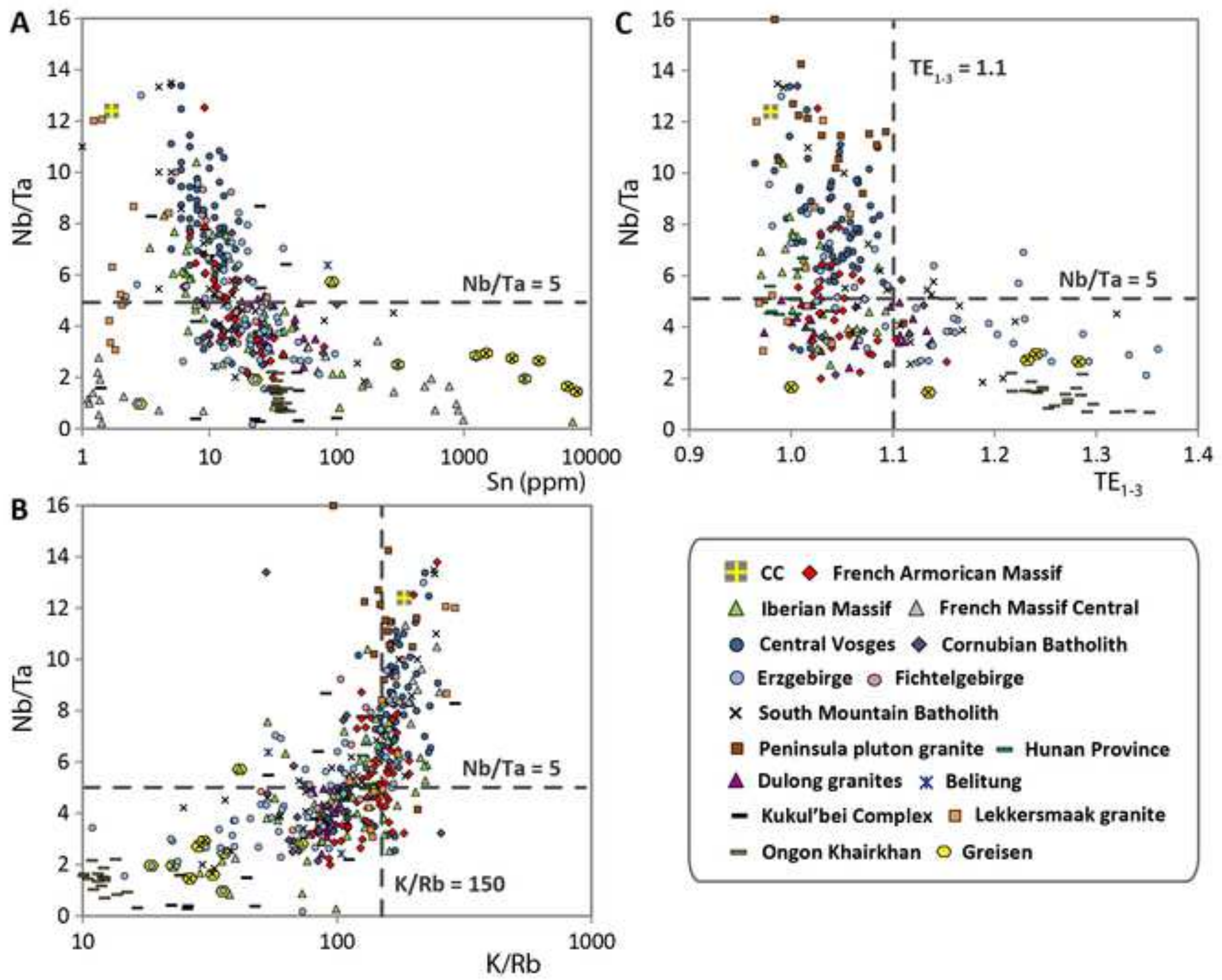

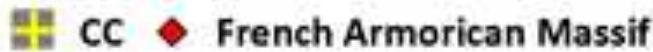

$\Delta$ Iberian Massif $\Delta$ French Massif Central

- Central Vosges $\diamond$ Cornubian Batholith

- Erzgebirge $\circ$ Fichtelgebirge

$\times$ South Mountain Batholith

a Peninsula pluton granite - Hunan Province

$\Delta$ Dulong granites $X$ Belitung

- Kukul'bei Complex $\square$ Lekkersmaak granite

- Ongon Khairkhan $\bigcirc$ Greisen 


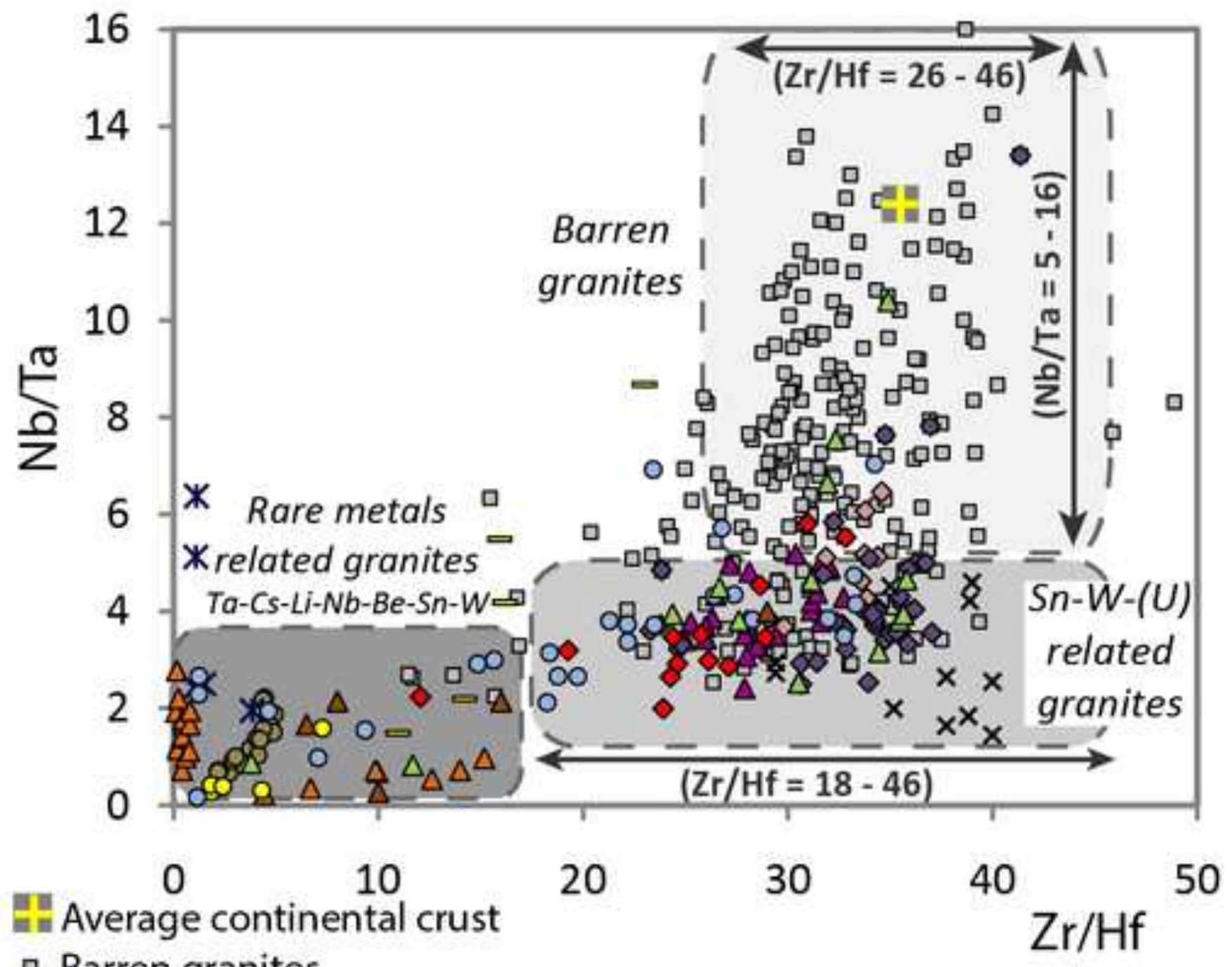

$\square$ Barren granites

$\diamond$ Lizio granite - Armorican Massif : Sn

- Questembert and Guérande granites - Armorican Massif : U - (Sn)

$\triangle$ Beariz, Jalama and Carbalinno granites - Iberian Massif : Sn - W - (Nb - Ta)

- Cornubian batholith : Sn - W - (Cu)

- $\mathbf{L i}$ - mica granites and greisens from the Erzgebirge : $\mathbf{S n}-\mathbf{W}$

$\times$ Leucogranites and greisens from the Davis Lake pluton - SMB : Sn

* Tanjungpandan pluton - Belitung - Indonesia: Sn-W

- Leucogranites from the Kukul'bei Complex - Transbaikalia: W - Sn

$\Delta$ Dulong granites - Yunnan Province - South China: Sn

- Ongonites from Ongon Kairkhan, Central Mongolia : W

- Li - F granites from the Kukul'bei Complex - Transbaikalia : Ta

$\Delta$ Beauvoir granite - Massif Central: $\mathbf{T a}-\mathbf{B e}-\mathbf{S n}-\mathbf{L i}$

$\Delta$ Ponte Segade granite-Iberian Massif : $\mathbf{S n}-\mathbf{T a}-\mathbf{N b}-\mathbf{L i}-\mathbf{B e}-\mathbf{C s}$ 
Click here to download Supplemental file DR1.docx $\underline{\underline{\underline{ }}}$

\begin{tabular}{|c|c|c|c|c|c|c|}
\hline Location & $\begin{array}{l}\text { Igneous } \\
\text { province }\end{array}$ & Granite & Age & & Related deposit & Reference \\
\hline \multirow{7}{*}{$\begin{array}{l}\text { Western } \\
\text { Europe }\end{array}$} & $\begin{array}{l}\text { French } \\
\text { Armorican } \\
\text { Massif }\end{array}$ & $\begin{array}{c}\text { Lizio } \\
\text { Questembert } \\
\text { Guérande } \\
\text { Huelgat } \\
\text { Brignogan } \\
\end{array}$ & $\begin{array}{c}\text { ca. } 316 \mathrm{Ma} \\
\text { ca. } 316 \mathrm{Ma} \\
\text { ca. } 310 \mathrm{Ma} \\
\text { Late Carboniferous } \\
\text { Late Carboniferous } \\
\end{array}$ & $\begin{array}{l}\text { Sn } \\
(U) \\
U-S n \\
- \\
-\end{array}$ & $\begin{array}{l}\text { U leached during hydrothermal alteration } \\
\text { Apical zone facies }\end{array}$ & $\begin{array}{c}\text { Tartèse and Boulvais, } 2010 \\
\text { Tartèse and Boulvais, 2010; } \\
\text { Tartèse et al., 2013 } \\
\text { Ballouard et al., } 2015 \\
\text { Georget, } 1986 \\
\text { Georget, } 1986\end{array}$ \\
\hline & Iberian massif & $\begin{array}{c}\text { Ponte Segade } \\
\text { Jalama } \\
\text { Beariz (Avion) } \\
\text { Beariz } \\
\text { Boboraz } \\
\text { Carballino } \\
\text { Irixo } \\
\text { Pedrobernardo } \\
\text { S. Mamede de Ribatua } \\
\text { Panasqueira } \\
\end{array}$ & $\begin{array}{c}\text { Late Carboniferous } \\
\text { Late Carboniferous } \\
\text { Late Carboniferous } \\
\text { Late Carboniferous } \\
\text { Late Carboniferous } \\
\text { Late Carboniferous } \\
\text { Late Carboniferous } \\
\text { c.a. } 300 \mathrm{Ma} \\
\text { Hercynian } \\
\text { Hercynian } \\
\end{array}$ & $\begin{array}{c}\text { Sn - Ta - Nb - Li -Be -Cs } \\
\text { Sn-W-(Nb-Ta) } \\
- \\
\text { Sn-W } \\
- \\
\text { Sn-W-(Nb-Ta) } \\
- \\
- \\
\text { Sn-W } \\
\text { Sn-W }\end{array}$ & & $\begin{array}{c}\text { Canosa et al., } 2012 \\
\text { Ramírez and Grundvig, } 2000 \\
\text { Gloaguen, } 2006 \\
\text { Gloaguen, } 2006 \\
\text { Gloaguen, } 2006 \\
\text { Gloaguen, } 2006 \\
\text { Gloaguen, } 2006 \\
\text { Bea et al., } 1994 \\
\text { Nieva, } 2002 \\
\text { Nieva, } 2002 \\
\end{array}$ \\
\hline & $\begin{array}{l}\text { French Massif } \\
\text { Central }\end{array}$ & $\begin{array}{c}\text { Colette } \\
\text { Beauvoir } \\
\text { Guéret } \\
\end{array}$ & $\begin{array}{l}\text { ca. } 310 \mathrm{Ma} \\
\text { ca. } 310 \mathrm{Ma} \\
\text { ca. } 350 \mathrm{Ma}\end{array}$ & $\begin{array}{c}- \\
\mathrm{Ta}-\mathrm{Be}-\mathrm{Sn}-\mathrm{Li} \\
-\end{array}$ & & $\begin{array}{l}\text { Raimbault et al., } 1995 \\
\text { Raimbault et al., } 1995 \\
\text { Rolin et al., } 2006 \\
\end{array}$ \\
\hline & $\begin{array}{c}\text { Cornubian } \\
\text { Batholith }\end{array}$ & - & 295-275 Ma & $\mathrm{Sn}-\mathrm{W}-(\mathrm{Cu})$ & & $\begin{array}{c}\text { Chappell and Hine, 2006; Müller } \\
\text { et al., } 2006\end{array}$ \\
\hline & Erzgebirge & - & Late Carboniferous - Early Permian & $S n-U-W$ & $\mathrm{Li}$ - mica granites and greisens & $\begin{array}{l}\text { Förster et al., 1999; Breiter, } \\
\text { 2012; Štemprok et al., } 2005\end{array}$ \\
\hline & Fichtelgebirge & - & Late Carboniferous - Early Permian & $?$ & & Hecht et al., 1997 \\
\hline & Central Vosges & - & $329-322 \mathrm{Ma}$ & - & & Tabaud et al., 2015 \\
\hline $\begin{array}{l}\text { Nova Scotia - } \\
\text { Canada }\end{array}$ & $\begin{array}{c}\text { South } \\
\text { Mountain } \\
\text { Batholith }\end{array}$ & $\begin{array}{c}- \\
\text { Davis Lake }\end{array}$ & $\begin{array}{l}\text { Late Devonian } \\
\text { Late Devonian }\end{array}$ & Sn & Topaz muscovite leucogranites and greisens & $\begin{array}{c}\text { MacDonald et al., } 1992 \\
\text { Dostal and Chatterjee, } 1995\end{array}$ \\
\hline \multirow{2}{*}{ South Africa } & $\begin{array}{c}\text { Kaapvaal } \\
\text { Craton }\end{array}$ & Lekkersmaak granite suite & ca. $2800 \mathrm{Ma}$ & - & & Jaguin, 2012 \\
\hline & $\begin{array}{c}\text { Cape Granite } \\
\text { Suite }\end{array}$ & Peninsula pluton & $556-534 \mathrm{Ma}$ & - & & Farina et al., 2012 \\
\hline \multirow{2}{*}{ South China } & Hunan Province & Indosinian granites & $210-243 \mathrm{Ma}$ & ? & & Wang et al., 2007 \\
\hline & $\begin{array}{l}\text { Yunnan } \\
\text { Province } \\
\end{array}$ & Dulong granites & ca. $90 \mathrm{Ma}$ & Sn & & Xu et al., 2015 \\
\hline Indonesia & Belitung & Tanjungpandan pluton & ca. $215 \mathrm{Ma}$ & $S n-W$ & & Schwartz and Surjono, 1990 \\
\hline $\begin{array}{c}\text { Eastern } \\
\text { Transbaikalia }\end{array}$ & - & Kukul'bei complex & ca. $140 \mathrm{Ma}$ & $\begin{array}{c}\mathrm{W}-\mathrm{Sn} \\
\mathrm{Ta}\end{array}$ & $\begin{array}{c}\text { Muscovite leucogranites (phase 2) } \\
\text { Albite-amazonite Li-F granites (phase 3) }\end{array}$ & Zaraisky et al., 2009 \\
\hline $\begin{array}{l}\text { Central } \\
\text { Mongolia }\end{array}$ & - & Ongon Khairkhan & Сa. $120 \mathrm{Ma}$ & W & $\begin{array}{l}\text { Ongonites (topaz bearing albite-rich } \\
\text { microleucogranites }\end{array}$ & Dostal et al., 2015 \\
\hline
\end{tabular}

Table DR1: Synthesis of the peraluminous granites reported in this study with their location, their age, their associated metal deposits when available and the corresponding references. 


\section{REFERENCES}

Ballouard C., Boulvais P., Poujol M., Gapais D., Yamato P., Tartèse R., Cuney M., 2015, Tectonic record, magmatic history and hydrothermal alteration in the Hercynian Guérande leucogranite, Armorican Massif, France: Lithos, v. 220-223, 1-22, doi:10.1016/j.lithos.2015.01.027.

Bea, F., Pereira, M.D., Corretgé, L.G., Fershtater, G.B., 1994, Differentiation of strongly peraluminous, perphosphorus granites: The pedrobernardo pluton, central Spain, Geochimica et Cosmochimica Acta: v. 58, 2609-2627, doi:10.1016/0016-7037(94)90132-5.

Breiter, K., 2012, Nearly contemporaneous evolution of the A- and S-type fractionated granites in the Krušné hory/Erzgebirge Mts., Central Europe: Lithos, A-type granites and related rocks through time "International Conference on A-type Granties and Related Rocks through Time", August 2010, Helsinki, Finland. 151, 105-121, doi:10.1016/j.lithos.2011.09.022.

Canosa, F., Martin-Izard, A., Fuertes-Fuente, M., 2012, Evolved granitic systems as a source of rare-element deposits: The Ponte Segade case (Galicia, NW Spain): Lithos, Seventh Hutton Symposium on Granites and Related Rocks 153, 165-176, doi:10.1016/j.lithos.2012.06.029

Chappell, B.W., Hine, R., 2006, The Cornubian Batholith: an Example of Magmatic Fractionation on a Crustal Scale: Resource Geology, v. 56, 203244, doi:10.1111/j.1751-3928.2006.tb00281.x.

Dostal, J., Chatterjee, A.K., 1995, Origin of topaz-bearing and related peraluminous granites of the Late Devonian Davis Lake pluton, Nova Scotia, Canada: crystal versus fluid fractionation: Chemical Geology, v. 123, 67-88, doi:10.1016/0009-2541(95)00047-P.

Dostal, J., Kontak, D.J., Gerel, O., Gregory Shellnutt, J., Fayek, M., 2015. Cretaceous ongonites (topaz-bearing albite-rich microleucogranites) from Ongon Khairkhan, Central Mongolia: Products of extreme magmatic fractionation and pervasive metasomatic fluid: rock interaction: Lithos, v. 236-237, 173-189. doi:10.1016/j.lithos.2015.08.003.

Farina, F., Stevens, G., Villaros, A., 2012, Multi-batch, incremental assembly of a dynamic magma chamber: the case of the Peninsula pluton granite (Cape Granite Suite, South Africa): Mineralogy and Petrology, v. 106, 193-216, doi:10.1007/s00710-012-0224-8.

Georget, Y., 1986, Nature et origine des granites peralumineux à cordiérite et des roches associées. Exemples des granitoides du Massif Armoricain (France): Pétrologie et géochimie [Ph.D. thesis] : Université Rennes 1, 298p.

Gloaguen, E., 2006, Apports d'une étude intégrée sur les relations entre granites et minéralisations filoniennes (Au et Sn-W) en contexte tardiorogénique (Chaîne Hercynienne, Galice centrale, Espagne) [Ph.D. thesis] : Université d'Orléans, 574p.

Förster, H.-J., Tischendorf, G., Trumbull, R.B., Gottesmann, B., 1999, Late-Collisional Granites in the Variscan Erzgebirge, Germany: Journal of Petrology, v. 40, 1613-1645, doi:10.1093/petroj/40.11.1613.

Hecht, L., Vigneresse, J.L., Morteani, G., 1997, Constraints on the origin of zonation of the granite complexes in the Fichtelgebirge (Germany and Czech Republic): evidence from a gravity and geochemical study: Geol. Rundsch, v. 86, S93-S109, doi:10.1007/PL00014669.

Jaguin, J., 2012, Datation et caractérisation de processus minéralisateurs à l'Archéen : Application à l'Antimony Line, Ceinture de Roches Vertes de Murchison, Afrique du Sud [Ph.D. thesis] : Université Rennes 1, 350p.

MacDonald, M.A., Home, R.J., Corey, M.C., Ham, L.J., 1992, An overview of recent bedrock mapping and follow-up petrological studies of the South Mountain Batholith, southwestern Nova Scotia, Canada: Atlantic Geology, v. 28.

Müller, A., Seltmann, R., Halls, C., Siebel, W., Dulski, P., Jeffries, T., Spratt, J., Kronz, A., 2006, The magmatic evolution of the Land's End pluton, Cornwall, and associated pre-enrichment of metals: Ore Geology Reviews, v. 28, 329-367.

Neiva, A.M.R., 2002, Portuguese granites associated with Sn-W and Au mineralizations: Bulletin of the Geological Society of Finland, v. 74, Parts $1-2,79-101$. 
Raimbault, L., Cuney, M., Azencott, C., Duthou, J.-L., Joron, J.L., 1995, Geochemical evidence for a multistage magmatic genesis of Ta-Sn-Li mineralization in the granite at Beauvoir, French Massif Central: Economic Geology, v. 90, 548-576. doi:10.2113/gsecongeo.90.3.548.

Ramírez, J.A., Grundvig, S., 2000, Causes of geochemical diversity in peraluminous granitic plutons: the Jálama pluton, Central-Iberian Zone (Spain and Portugal): Lithos, v. 50, 171-190, doi:10.1016/S0024-4937(99)00047-X.

Rolin, P., Cartannaz, C., Henry, P., Rossy, M., Cocherie, A., Salen, F., Delwaulle, B., Mauroux, B., 2006, Notice explicative, Carte géologique de la France, échelle : 1/50 000, feuille Saint-Sulpice-les-Champs (666), Orléans : BRGM, 178 p.

Schwartz, M.O., Surjono, 1990, Greisenization and albitization at the Tikus tin-tungsten deposit, Belitung, Indonesia: Economic Geology, v. 85, 691-713, doi:10.2113/gsecongeo.85.4.691.

Štemprok, M., Pivec, E., \& Langrová, A., 2005, The petrogenesis of a wolframite-bearing greisen in the Vykmanov granite stock, Western Krušné hory pluton (Czech Republic): Bulletin of Geosciences, v. 80(3), 163-184.

Tabaud, A.-S., Janou ek, V., Skrzypek, E., Schulmann, K., Rossi, P., Whitechurch, H., Guerrot, C., Paquette, J.-L., 2015, Chronology, petrogenesis and heat sources for successive Carboniferous magmatic events in the Southern-Central Variscan Vosges Mts (NE France): Journal of the Geological Society, v. 172, 87-102. doi:10.1144/jgs2013-12

Tartèse, R., Boulvais, P., 2010, Differentiation of peraluminous leucogranites "en route” to the surface: Lithos, v. 114, 353-368, doi:10.1016/j.lithos.2009.09.011.

Tartèse, R., Boulvais, P., Poujol, M., Gloaguen, E., Cuney, M., 2013, Uranium Mobilization from the Variscan Questembert Syntectonic Granite During Fluid-Rock Interaction at Depth: Economic Geology, v. 108, 379-386. doi:10.2113/econgeo.108.2.379

Wang, Y., Fan, W., Sun, M., Liang, X., Zhang, Y., Peng, T., 2007, Geochronological, geochemical and geothermal constraints on petrogenesis of the Indosinian peraluminous granites in the South China Block: A case study in the Hunan Province: Lithos, v. 96, 475-502, doi:10.1016/j.lithos.2006.11.010.

Xu, B., Jiang, S.-Y., Wang, R., Ma, L., Zhao, K., Yan, X., 2015, Late Cretaceous granites from the giant Dulong Sn-polymetallic ore district in Yunnan Province, South China: Geochronology, geochemistry, mineral chemistry and Nd-Hf isotopic compositions: Lithos, v. 218-219, 54-72. doi:10.1016/j.lithos.2015.01.004.

Zaraisky, G.P., Aksyuk, A.M., Devyatova, V.N., Udoratina, O.V., Chevychelov, V.Y., 2009, The Zr/Hf ratio as a fractionation indicator of raremetal granites: Petrology, v. 17, 25-45, doi:10.1134/S0869591109010020. 